\title{
"Langen Tayub Padang Bulan" As A Manifestation of Social and Cultural Change in Community
}

\author{
${ }^{\otimes}$ Anik Juwariyah \\ Department of Drama, Dance, and Music, \\ Faculty of Languages and Arts, Universitas Negeri Surabaya, Indonesia
}

Received: August 30, 2018. Revised: October 23, 2018. Accepted: December 4, 2018

\begin{abstract}
This study examines Langen Tayub's artistic position in social and cultural changes in society, especially in Nganjuk Regency. Langen Tayub as a product of a society that has undergone a change, also made innovations in Nganjuk community, this innovation was manifested in the form of a performance called Langen Tayub Padang Bulan. The research methods used include: Qualitative research approaches, data collection techniques uses: interviews, observation, documentation and recording. Data analysis used is the Talcott Parsons theory abbreviated as AGIL (A (adaptation), Achievement Goals (G-goal attainment), I (Integration), and L (latency) or pattern maintenance. Results showed that as a traditional cultural product, Langen Tayub experienced the changing form of presentation: Social and cultural changes that have taken place in the community have shifted the old model of Langen Tayub to Langen Tayub Padang Bulan, with some special characteristics that are adapted to the present conditions of society.
\end{abstract}

Keywords: Langen Tayub Padang Bulan; Social and Cultural Change; Society

How to Cite: Juwariyah, A. (2018). "Langen Tayub Padang Bulan" As A Manifestation of Social and Cultural Change in Community. Harmonia: Journal of Arts Research And Education, 18(2), 191-199.

\section{INTRODUCTION}

As a traditional performing art that still exists, Langen Tayub is supported by the solid construction of various supporting elements. It is very interesting to be observed, considering that from the current era, the position of traditional arts is very important in its position to support the development of national culture as well as a cultural identity that needs to be continuously preserved and developed.

Langen Tayub has Symbolic meaning (Based on the concept of Clifford Geertz, Tayub dance for clean village ceremonies is to have a meaning of fertility, safety, and community solidarity or harmony. Kayam
(1985) says that village cleaning is a tribute to Dewi Sri (goddess prosperity/rice). Ahmad Tohari (1992) states that Tayub's oldest function is for fertility ceremonies. Suharto (1999) explains that Tayub dance in the midst of society also carries a sacred duty, because it becomes the center of village cleaning ceremonies, rasulan (after harvest), ruwatan, nadaran etc. The Tayub dance is closely related to fertility which is symbolized by the relationship between men and women which is a symbol of hope for fertile plants).

According to Soedarsono (1991, p. 35) in an agrarian culture, fertility is the only hope that is always coveted by farmers. In the minds of traditional farmers,

\footnotetext{
Corresponding author: Jl. Lidah Wetan, Surabaya, Jawa Timur 60231, Indonesia

E-mail: anikjuwariyah@unesa.ac.id
} 
soil fertility is never enough by only achieved through the improvement of new agricultural systems, but it also needs to strive through intangible forces. Thus, it can be translated that the traditional farmers in their efforts to achieve agricultural fertility to succeed well, not only through rational means, but also make contact with the magical powers (irrational) in the form of ceremonies. This symbolic relationship seems to be the background of the presence of Tayub, a ritual for fertility, both fertility in the form of fertilizing agricultural products, as well as fertility for marriage.

Sudikan (1997) states that: "Folk performing arts have a characteristic that is simple, spontaneous, belongs to the community and from the community, and unites with the lives of the people" (This understanding in Central and East Java is usually contradicted with the palace performing arts which are said to have been born in the palace environment so that it appears the impression of "adiluhung" (realizing virtue, "maintained", graceful and smooth). Various folk art performances will be known as traditional arts if the art comes from and can be felt by the supporting community.

Art, presents, develops and is standardized through the social traditions of a society. As with other cultural elements, art also functions to sustain and preserve community togetherness (Rohidi, 2009).

Development era demands that the form of Langen Tayub's presentation that is vulgar, erotic and impolite becomes the public's spotlight and needs to be concerned. It seems that the form of Langen Tayub's presentation of the old model also occurs in similar art forms as said by Weintraub, (2008). In his writing, he highlighted the social and political contributions of authority and power during the turbulent period of Indonesian history carried out on stage and recorded in various discursive fields, including oral. According to Weintraub, many people, and newspapers and personal accounts characterize scenes inspired by singers as carnivalesque, chaotic, and sometimes even violent. In 1959
64, it was considered as a "sinden crisis", which coincided with Soekarno's Guided Democracy (1959-65), a period in Indonesian history characterized by a weakening of the state, economic difficulties, and rampant political pragmatism.

Based on this description, the purpose of this research is to examine Langen Tayub's position in social and cultural changes in society, especially in Nganjuk Regency.

\section{METHOD}

This study uses a qualitative approach, with researchers as the main instrument in the research process. The researcher chose qualitative research with the aim to be able to know the phenomenon of Langen Tayub's art construction in natural conditions in everyday life in society. Denzim and Yvonna S. Lincoln (2000: 670) state that constructionist interpretation always adheres to reliable or reliable empirical materials. Reliability itself includes four main components, namely credibility, transferability, dependability, and confirmability. Data collection techniques used in this study are: (1) interviews, (2) observation, (3) documentation, and (4) recording. Data analysis uses the theory of social change in society. Data analysis uses Talcott Parsons's theory abbreviated as AGIL (A (adaptation), Achievement of Goals (G-goal attainment), I (Integration), and L (latency) or pattern maintenance.

\section{RESULTS AND DISCUSSION}

\section{The Concept and Presentation of the Old Model Langen Tayub}

Langen Tayub's old model was the term for the presentation of Langen Tayub held by the community before the Tayub Padang Bulan was socialized. Langen Tayub's old model became a forum for Langen Tayub community members to express and carry on their freedom. If in their daily lives they are not free to drink liquor, etc., then in the performance of Langen Tayub they can freely drink to their heart's 
content. In the presentation, Langen Tayub has the following characteristics:

Dancers, performers and pengrawit are in one level, there is no separation of Langen Tayub's actors with the stage. They are on the floor with carpet or mats.

In the dancing arena, the distance of dancers and penayub is free, can be both very close and in a distance. In performances where the number of penayub and the waranggana are many, the stage looks crowded. In this condition, it is very possible for the impolite penayub to tempt waranggana, there is someone who pinches, kisses and even acts more disrespectful.

Saweran for waranggana (dancer Langen Tayub) is given by means directly on stage or during the ndara-ndara phase. Often this opportunity is used by a naughty penayub to give saweran by laying a hand in a way between breasts.

Taking a turn of gendhing can be done at any time. In the request for a change in gendhing accompanied by saweran (cash) for pengrawit. Frequently, there is a fight between penayub because of fighting over the gendhing. The newly sung Gendhing can be replaced immediately. It is a very rare situation where gendhing can be sung until it's finished. With conditions like this, those who dance also seem chaotic, because it cannot be enjoyed, yet the gendhing takes a turn to change.

The show last for an overnight. In the old Langen Tayub model, the performance was carried out from 21.00 WIB to 04.00 WIB (before dawn). As a result of the all-night performance, those who are involved in the show are not able to do normal work the next day. Besides that, shows that last night can disrupt the surrounding environment, which is likely to be less or not like the performance of Langen Tayub.

The debate of sensuality in some shows in Indonesia has become an interesting national debate for some groups, especially with the culture of nyawer given to performers in an irreverent manner. As the point in the dangdut show, Bader \& Richter, (2014) states that through the interaction of menyawer on the stage between sin- gers and penyawer it can continue off-stage which is a fierce conservative discourse by academics. They consider this to be a matter of feminist discourse about exploitation and empowerment.

Women's sexuality and what is called by Bader (2011, 2013) as 'nyawer meeters' have long been a hallmark of traditional Javanese and Sundanese arts and performances. Richter (2008) called these forms as 'other worlds' physical movements among players. Beautiful women on the stage are considered to have magical powers to seduce men from their wives. Their attitude on stage often has sexual connotations (Peacock, 1967).

\section{Concept and Presentation of Tayub Padang Bulan}

In decades, Langen Tayub in the community had a bad impression, resulting from drinking and negative things that accompanied it. Based on this, the parties involved compiled a new formula / concept with the hope that it would be more acceptable to the wider community. Langen Tayub Nganjuk experienced a change in the form of presentation. The idea was made by the Head of the Nganjuk District Tourism and Culture Office in 2006, Tri Wiyosoputra. The concept of the idea is Langen Tayub Padang Bulan.

This concept was inspired by the Padang Bulan performance of Kyai Kanjeng by Emha Ainun Najib. With the idea that in ancient times there was a crowd usually carried out on the full moon. With that expectation, the performance of Langen Tayub was carried out routinely every month at Langen Tayub Workshop art (Summarized from the results of Interview with Triwiyosoputro as Head of the Nganjuk and Waras as the Head of Disparbudda of Nganjuk, the Head of Culture Section Disparbudda of Nganjuk Regency on September 24th, 2009 in Disparbudda Office of Nganjuk District). After two years running, Langen Tayub Padang Bulan was held in rotation in the sub-districts in Nganjuk Regency, so it was not staged in only one place. By applying this way, it 
seems that it is even more able to stimulate life in rural communities.

Now, the special rules for the performance of Langen Tayub Padang Bulan are as follows.

Gamelan on the stage is approximately 40 $\mathrm{cm}$ from the floor

The provisions of the gamelan are placed on the stage are an attempt to lift the position of the gamelan, so that the audience can see it. With the existence of the stage, it is possible to enjoy it up to a distance away.

\section{Stage Height}

The stage for dancing must be approximately $20 \mathrm{~cm}$ from the floor. The existence of a stage for dancing waranggana and penayub, it aims to elevate the dignity of Langen Tayub performers. Besides, it is aimed for those who are dancing on stage can be enjoyed their beauty. In the old Langen Tayub concept (before Tayub Padang Bulan), where there was no stage was very possible to be only in one Tayuban area, the number of penayub could not be limited and the atmosphere became crowded. In this case, the beauty of Langen Tayub is less enjoyable. Besides that, it is very possible for penayub to do indecent things. For more details, see Figure 1.

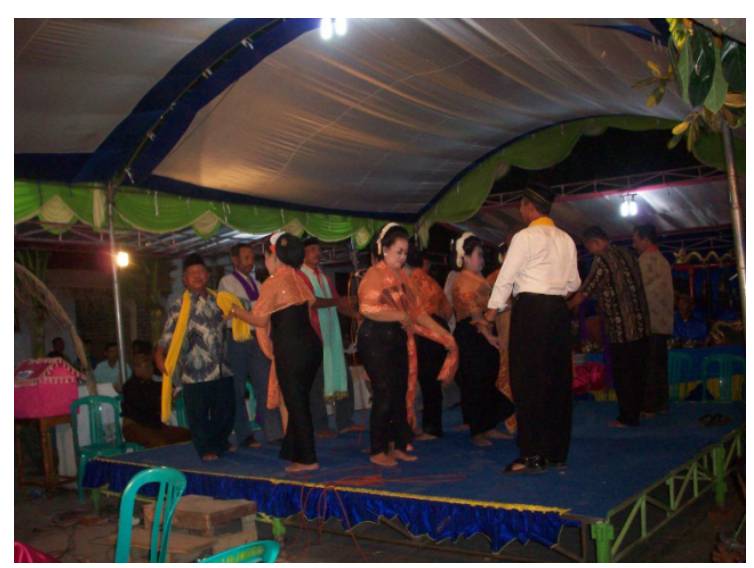

Figure 1. The Number of Penayub

\section{Clothing for Pengrawit, Stewardess and Waranggana}

The wearing of Kejawen clothing is a form of adherence of Langen Tayub per- formers to the ancestral heritage and a respect for the elements of Javanese culture. By wearing traditional Javanese attire, they mean preserving ancestral heritage.

Before Langen Tayub began, pramugari read Langen Tayub's ethics or orders about the rules of the tayub performance that were allowed. Penayub must be welldressed, dressed and trousers (not shirts and / or training). The need for penayub to be well-dressed is expected to match the appearance of waranggana, pramugari and pengrawit. By dressing neatly, people will be more appreciative, than in staging penayub wearing training or other casual clothes.

\section{Amount of Penayub and Waranggana}

Penayub that gets sampur must match the number of waranggana when performing. This rule is arranged so that the beauty of the performance of Langen Tayub can be enjoyed, also to make it look more organized and orderly. By limiting the number of penayub on stage, a maximum of two times the number of waranggana, then the possibility of penayub to do less polite can be avoided.

\section{Giving Tips to Waranggana}

Giving tips to Waranggana is only given through shaking hands or placing it on trays. It was common knowledge that Langen Tayub was close to irreverent acts, such as giving a sawer to the dancer's chest, or a drunken penayub. However, both of these things are a serious concern of the tourism department and other related parties. So now how to give a tip or sawer is given by handshake.

\section{The opportunity Mengibing for Penayub}

Penayub is given the opportunity to give a maximum of 3 gendhing sequentially until the last song-poem has finished (there is no gendhing rotation in the middle of gendhing playing).

This order clearly intends to minimize the chaos that is often caused by the competition of sudden demand for gendhing from penayub. By giving a sawer in 
the middle of the gendhing, penayub tried to show their selfishness which eventually became a source of contention among penayub and the performance could be chaotic. With this rule, Langen Tayub can also be more enjoyable. The person who listened to Langen Tayub's performance from a distance could listen well to the singing that was sung.

For waranggana (dancer Langen Tayub) group, the Langen Tayub Padang Bulan model is said to be better, as stated by waranggana, Sriatun (Interview with Sriatun, February 18th, 2012 at 14.00 to 16.00 WIB in East Java Cultural Park, Jl. Gentengkali 85 Surabaya): "It is better for Tayub Padang Bulan, because it is more organized, more polite, more enjoyable and rare until there is a riot, because the gendhing is sung until the gendhing is finished not cut off in the middle of the playing".

\section{Gendhing Fee}

The cost of gendhing is only given through pramugari when penayub rises on stage. The cost of gendhing given through pramugari minimizes the efforts of penayub who want to be rude to Waranggana. The cost of this gendhing is usually placed on a plate or tray.

\section{Distance Penayub with Waranggana}

The distance of penayub / penayub with waranggana performing time is at least one meter. The old Langen Tayub model that did not limit the number of penayub who danced with waranggana resulted in chaotic performances. The distance of dancers who are too close gives an opportunity for those who are not polite to do bad things. Langen Tayub's performance also became less enjoyable for aesthetics.

\section{Prohibition of Smoking on the Stage}

Smoking on stage is very dangerous for waranggana and other penayub. For this reason, as long as penayub dance with the dancers, they are prohibited from smoking. Smoking is allowed when sitting at a table with their community.

\section{Prohibition of Smoking in the Stage Are-} na

Prohibition of drinking liquor on stage also aims to create beautiful and enjoyable performances as prevention of disturbance made by drunken penayub who continue drinking on stage to make chaos. Penayub who drink on stage can have less control over themselves, and that is dangerous for others.

\section{Prohibition of carrying sharp weapons or firearms}

Bringing a sharp weapon / firearms is strictly prohibited at the stage, except for officers, because if someone brings that prohibited object and this person who is drunk can endanger others. Security officers are allowed to carry weapons because they are in charge of maintaining security during the show.

\section{Stage time}

The end of stage time is $24.00 \mathrm{WIB}$. Langen Tayub's performance which lasted until early morning can cause disruption to the surrounding environment. Besides, the performance above 12 a.m., sometimes it is less manageable, such as performance in Tempuran Village (Observation of the Langen Tayub show at Pardani's house, Tempuran Village, Ngluyu District, Nganjuk Regency, April 25th, 2012), the performance above 12 a.m. is dominated by the younger generation.

Langen Tayub's performance in the context of social and cultural changes

The study of tayub performances in the context of social and cultural change, the researchers used Talcot Parson's theory, which gave birth to the concept of AGIL. According to Parsons in (Ritzer, 2004) a function is a group of activities directed at meeting one or two system requirements". There are four functional imperatives needed by the whole system, namely: A (adaptation), Achievement of Goals (G-goal attainment), I (Integration), and L (latency) or pattern maintenance. The four altogether are called the AGIL 
scheme. In order to survive, the system must carry out these four functions. The condition of the langen tayub art in Nganjuk district when examined with the AGIL concept from Parsons is as follows:

\section{Adaptation}

Adaptation (A) implies that the system must address situational needs that come from outside. It must adapt to the environment and adapt the environment to its needs. In Langen Tayub's art, the efforts made by the parts of the system to adapt were done by:

Continuously renewing gending which are sung in the performance of Langen Tayub. Gending Campur Sari that is currently popular also often played, such as: bojo loro, rujak jeruk, Alun-alun Nganjuk, etc.

The design of the stage has undergone some changes from the level of the ground, now elevated higher than the spectators, the place of the gamelan is even higher.

The hour of the show also changes, if the previous performance lasts until dawn or even more, now it is maximal at 02.00 a.m. which frequently happened only until 12:00 p.m.

The dancing distance between tayub dancers / waranggana and pengibing is not too close, about one meter. Even though it could be full if there are plenty of waranggana on the stage, and the distance among the dancers cannot be far apart.

Waranggana makeup and clothing are also better than it was before, they look more beautiful and are more able to dress up.

The Disparbudda of Nganjuk Regency as an institution which responsible for increasing the potential of this art also continues to provide guidance to the artists of tayub, both waranggana, pengrawit and also for pengibing. This is done so that the artists are not outdated and always on the path outlined. Coaching material is directed at aesthetic and ethical aspects in the arts. As shown in the following figure:

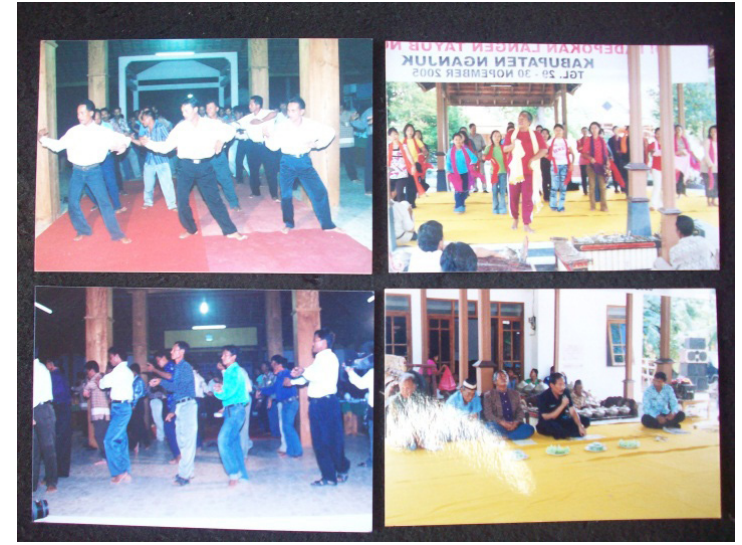

Figure 2. Training for tayub artists by the Disparbudda Nganjuk

In general, the form of adaptation carried out is the concept of Langen Tayub Padang Bulan, which is now a concept that is always carried out in any performance of the tayub.

\section{Goal Attainment}

Goal attainment $(G)$ means that the system must define and achieve its main objectives. In relation to the determination and achievement of these objectives, it is clear that the system that regulates the implementation and guidance of staging takes various efforts, so that the goal of preserving this traditional culture runs well and is supported by the local government.

\section{Integration}

Integration (I) means that the system must regulate the relationship of the parts that become its components. It also must regulate the relationship between the three functional imperatives.

For the integration process, which is the arrangement of relations among these parts is clearly seen in the flow of activities that need to be done by tayub artists in performing the show. There is a path that these tayub artists and the community must go through to hold a Langen Tayub performance. For those who have the interest, they must get a staging permit at the local police station. The granting of stage permits is important to control so that the performance runs in an orderly manner 
and does not interfere with other community activities. The form of permission granted by the local police station will be installed in front of the house of a person who has an interest.

\section{Latency}

Latency $(\mathrm{L})$ (maintenance of the pattern) means that the system must complete, maintain and renew individual motivation and cultural patterns that create and maintain that motivation.

Disparbudda as a motivator, the driver of the running of this traditional art so that it can continue to develop and be accepted by the community to take several actions, including issuing the concept of Tayub Padang Bulan with various innovations such as (1) attending invitations from the people who held Langen Tayub performances, (2 ) conduct training by training new gendhing and movement to the waranggana, holding gambyong dance competitions / festivals for the waranggana, and (3) holding gembyongan waranggana with various variations in its applications; etc. In the evenings show, they did not hesitate to go directly to the field, both to review and motivate them, the tayub artists, to continue developing this traditional art.

The description above shows that in order Langen Tayub art to survive, the system must carry out these four functions, namely adaptation, purpose, integration, and pattern maintenance. As Parson said, based on structural-functional assumptions can be explained further as follows.

The system has an order and parts that depend on each other, can be seen in how each component in the Langen Tayub performance system provides positive support for a change made, both changes in rules and concepts of implementation.

The system tends to be the order that maintains itself, or equilibrium. With some changes to the rules for organizing the Langen Tayub stage, it is clear that the existing order will be well-maintained, both local customs, forms of art and the existing social system. Everything is created for an equilibrium state, a balance.
The system can become static or undergo an orderly process of change. With the concept of Tayub Padang Bulan, the process of change has indeed been laid out beforehand and planned carefully. Not only that, the motivation given by the Disparbudda on the elements of the performance of the Langen Tayub has made the arrangement to be carried out as expected.

The nature of one part of the system has an impact on the possibility of other parts. The nature of one of the elements in progressive and positive Langen Tayub performing arts clearly has a positive impact on other elements. In this case the nature of "picking up the ball" from the Disparbudda brings a good spirit for tayub artists to continue developing while preserving the art of this tradition.

The system maintains boundaries with their environment. It is clear that the norm limits applied to the performance of Langen Tayub are an embodiment of the rules that exist in their environment.

Allocation and integration are two fundamental processes needed for equilibrium conditions of the system. The system surrounding Langen Tayub art is a solid basis for the creation of an existing balance or equilibrium system. The unification of elements in the Langen Tayub art becomes a unifying relationship in the existing social system.

Hauser (1982) explains that social change in a region will produce a distinctive style of art, in accordance with the form of society at that time. A type of art which at a certain period is ritual art, can become a popular art in the next period. A type of art that originally functions as a religious rite in a particular era can be a means of power, and eventually becomes a commodity / market.

In line with Hauser's opinion, the development of Langen Tayub now shows its function more towards art for entertainment. The folk art which used to be for the sake of fertility rituals, is now more dominant as entertainment for both men and women. Nevertheless the function of entertainment is still dominated by men. In 
the Big Indonesian Dictionary (1990: 909) it was stated that the tayuban is a dance performed by men and women accompanied by gamelan and songs usually to enliven the party (marriage, a feast celebrating s circumcision, etc.). Hidajat (2014, p. 73) states that in tayub performances generally requires a dancer who can perform very well with continuous dancing movements, sweet voice, slim body, and beautiful face. This is according to Hidayat (2014), as an ideal criterion in tayub performances. Various strategies were taken to make waranggana acceptable to Tayub worshipers. However, the number of waranggana can increase from year to year, adjusting the intent and purpose of the event.

\section{CONCLUSION}

Art is dynamic. As social and cultural changes in the art community which originally functioned as rituals, the function will eventually turn into an entertainment art. The Langen Tayub Padang Bulan concept that is currently being implemented in the Langen Tayub performing art in Nganjuk shows evidence of that. The life values of the traditions contained in Langen Tayub will eventually be displaced by the concepts offered by the government (tourism and cultural services) of Nganjuk Regency, for example in the rules on the number of gendhing that may be carried out by the penayub. The old Langen Tayub model made this art an arena for people's freedom in the countryside to express their artistic value. The klangenan element which is limited by limiting the number of gendhing requested in accordance with the provisions of Langen Tayub Padang Bulan made fanatical Langen Tayub actors feel less satisfaction. In addition, the arrangement has obscured the notion of folk art that Langen Tayub carried with prominent features that are simple, spontaneous, belonging to the community and from the community, and united with simple and free people's lives without binding rules.

\section{REFERENCES}

Bader, S., \& Richter, M. M. (2014). Dangdut Beyond the Sex: Creating Intercorporeal Space through Nyawer Encounters in West Java, Indonesia. Ethnomusicology Forum, 23(2), 163-183. https://doi.org/10.1080/17411912.2 014.926629

Hauser, A. (1982). The Sociology of Art. USA : The University of Chicago.

Hidayat, R. (2014). The Popularity of Waranggana Tayub Malang Through Body Exploitation. Harmonia: Journal of Arts Research and Education, 14(2), 72-77.

Kayam, U. (1981). Seni, Tradisi dan Masyarakat. Jakarta: Sinar Harapan.

Ritzer, G. \& Douglas J. G. (2004). Teori Sosiologi Modern. Jakarta: Kencana.

Rohidi, T. R. (2009). Kesenian Tradisional "Nusantara" Bahasan tentang Warisan dalam Konteks Perubahan Budaya" Makalah. In Seminar Nasional Pengembangan Kesenian Tradisional dalam Kebudayaan Kontemporer. Semarang: i Universitas Negeri Semarang.

Salim, A. (2002). Perubahan S

osial, Sketsa Teori dan refleksi Metodologi Kasus Indonesia. Yogyakarta: Tiara Wacana.

Soedarsono. (1972). Jawa dan Bali Dua Pusat Pengembangan Kesenian Tradisional Indonesia. Yogyakarta: Gajahmada University Press.

Soedarsono, R. M. (2002). Seni Pertunjukan Indonesia di Era Globalisasi. Yogyakarta: Gajah Mada University Press.

Sudikan, S. Y. (1997). Tantangan Seni Pertunjukan Rakyat(Tradisional) dalam Menghadapi Era Teknologi Komunikasi. Prasasti, 7, 12-23.

Suharto, B. (1999). Langen Tayub, Pertunjukan dan Ritus Kesuburan. Bandung: Masyarakat Seni Pertunjukan Indonesia (MSPI).

Sumardjo, J. (2000). Filsafat Seni. Bandung: ITB.

Supratno, H. (2010). Sosiologi Seni, Wayang Sasak Lakon Dewi Rengganis dalam Konteks Perubahan Masyarakat di 
Lombok. Surabaya: Unesa University Press.

Weintraub, A. N. (2008). The "Crisis of the Sinden": Gender, Politics, and
Memory in The Performing Arts of West Java, 1959-1964. In Popular Music, 27(3), 367-392. doi:10.1017/ S0261143008102185. 